\title{
FUNGSI PENGAWAS DALAM PEMENUHAN STANDAR PENDIDIKAN MADRASAH DI KOTA SERANG BANTEN
}

\author{
Imran Siregar \\ Peneliti Puslitbang Pendidikan Agama dan Keagamaan \\ Badan Litbang dan Diklat Kementerian Agama Republik Indonesia \\ Jl. MH Thamrin No. 06 Jakarta Pusat \\ imran.siregar56@yahoo.com
}

\begin{abstract}
The fulfillment of national education standards has become mandatory for all educational institutions in the national law of the Republic Indonesia, which of course includes madrasah. Many efforts have been made both by the government and madrasah, yet the fulfillment of national education standards (SNP) still has not been successful. Problems do not only appear internally; they also appear externally, from supervisors. There is no doubt that supervisors also must be responsible in guiding and fulfilling the requirements of the national education standards (SNP). The reality found by the research shows that supervisors are not yet successful in guiding and mentoring systematically in order to support the national education standards (SNP) in the Madrasah. The awareness of SNP by supervisors still appears to be low; this is evident in the ineffectively-designed supervising and guidance program that is below the expectations of the SNP. The documents, related to guidance and mentoring, ]designed by the supervisor are considered mediocre based on the administrative procedures. Hence, many Madrasah(s) are still struggling in fulfilling the SNP that has become a national agreement.
\end{abstract}

Keyword: fulfillment, National Education Standard, Madrasah Supervision

\section{Abstrak}

Pemenuhan Standar Nasional Pendidikan adalah suatu keharusan bagi semua lembaga pendidikan di wilayah hukum Negara Kesatuan Republik Indonesia, tidak terkecuali madrasah. Berbagai upaya telah dilakukan oleh pemerintah maupun masyarakat madrasah, namun pencapaian Standar Nasional Pendidikan (SNP) masih tetap saja menghadapi berbagai kendala. Selain kendala internal madrasah dengan berbagai keterbatasannya, juga dihadapkan pada kendala eksternal dari pihak pembina madrasah seperti pengawas. Sesuai dengan fungsinya seyogianya pengawas juga dapat berperan penting dalam membimbing dan membina madrasah dalam pemenuhan SNP tersebut. Dalam realitas di lapangan ternyata menunjukan bahwa pengawas belum dapat melakukan pembinaan dan pemantauan yang terencana dalam upaya membantu madrasah dalam pemenuhan SNP. Pemahaman pengawas tentang SNP masih sangat terbatas, antara lain ditandai dengan cara mereka menyusun desain program dalam pelaksanaan pembinaan yang belum sesuai dengan yang diharapkan. Seperangkat kelengkapan dokumen yang dibuat oleh pengawas terkait dengan pembinaan dan pemantauan pemenuhan SNP baru sebatas pemenuhan persyaratan adiministratif kepengawasan.Tidaklah mengejutkan jika kemudian masih banyak madrasah yang kesulitan memenuhi SNP yang telah menjadi kesepakatan nasional tersebut.

Kata Kunci: Pemenuhan, Standar Nasional Pendidikan, Pengawas Madrasah

Naskah diterima 30 Januari 2013. Revisi pertama, 21 Februari 2013. Revisi kedua, 7 Maret 2013 dan revisi terahir 02 April 2013. 


\section{PENDAHULUAN}

Acuan mutu yang digunakan dalam pencapaian pendidikan yang berkualitas pada satuan pendidikan di Indonesia adalah Standar Nasional Pendidikan (Peraturan Pemerintah Nomor 19 Tahun 2005 tentang Standar Nasional Pendidikan) ${ }^{1}$. Standar Nasional Pendidikan (SNP) adalah standar yang dibuat oleh pemerintah. Sedangkan standar lain yang dibuat oleh satuan pendidikan dan/atau lembaga lain yang disepakati oleh kelompok masyarakat juga dapat dijadikan sebagai acuan tambahan yang memperkuat SNP. Standar-standar lain yang disepakati oleh kelompok masyarakat tersebut baru dapat digunakan setelah SNP buatan pemerintah dipenuhi terlebih dahuluoleh satuan pendidikan.

Standar Nasional Pendidikan, merupakan kriteria minimal tentang sistem pendidikan di seluruh wilayah hukum Negara Kesatuan Republik Indonesia. Dikeluarkannya Peraturan Pemerintah (PP) No.19 tahun 2005 tersebut, bertujuan untuk meningkatkan mutu pendidikan di Indonesia termasuk di dalamnya pendidikan madrasah. Adapun fungsinya adalah sebagai dasar dalam perencanaan, pelaksanaan dan pengawasan pendidikan dalam rangka mewujudkan pendidikan nasional yang bermutu.

Terdapat delapan SNP yaitu:

1. Standar Isi

2. Standar Proses

3. Standar Kompetensi Lulusan

4. Standar Kompetensi Pendidik dan Tenaga Kependidikan

5. Standar Sarana dan Prasarana

6. Standar Pengelolaan

7. Standar Pembiayaan

8. Standar Penilaian

Delapan SNP di atas memiliki keterkaitan satu sama lain dan sebagian standar menjadi prasyarat bagi pemenuhan standar yang lain-

${ }^{1}$ Peraturan Pemerintah Republik Indonesia Nomor 19 Tahun 2005 tentang Standar Nasional Pendidikan, pasal 4. nya. Dalam kerangka sistem, komponen input sistem pemenuhan SNP adalah Standar Kompetensi Pendidik dan Tenaga Kependidikan (PTK), Standar Pengelolaan, Standar Sarana dan Prasarana (Sarpras), dan Standar Pembiayaan. Bagian yang termasuk pada komponen proses adalah Standar Isi, Standar Proses, dan Standar Evaluasi, sedangkan bagian yang termasuk pada komponen output adalah Standar Kompetensi Lulusan (SKL).

Kaitan antar SNP ${ }^{2}$ digambarkan sebagai berikut:

Gambar 1: Kaitan antar Standar Nasional Pendidikan (SNP)

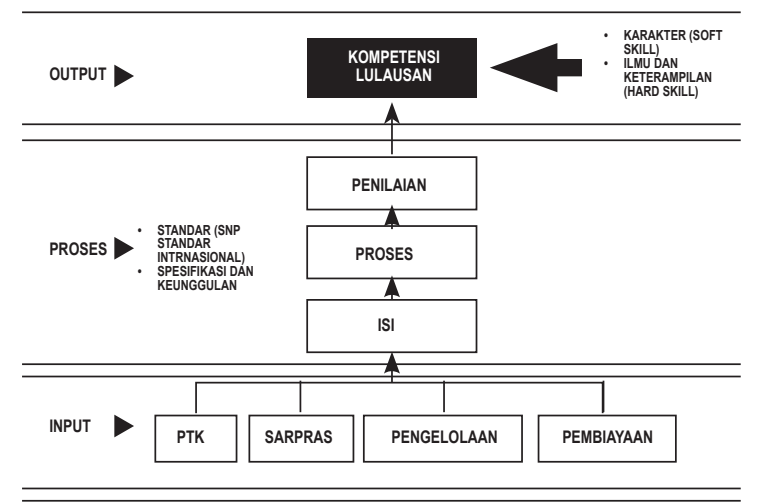

Pengawas adalah salah satu diantara unsur yang terakait dan berperan mempengaruhi mutu pendidikan madrasah. Pengawas madrasah mempunyai fungsi melakukan:

a. penyusunan program pengawasan di bidang akademik dan manajerial;

b. pembinaan dan pengembangan madrasah;

c. pembinaan, pembimbingan, dan pengembangan profesi guru madrasah;

d. pemantauan penerapan standar nasional pendidikan;

e. penilaian hasil pelaksanaan program pengawasan; dan

f. pelaporan pelaksanaan tugas kepengawasan.

${ }^{2}$ Kemdikbud.2012. Pedoman Pemenuhan SNP Sekolah/ Madrasah (Pusat Penjaminan Mutu Pendidikan). Jakarta.h.13 
Pengawas madrasah bertanggungjawab terhadap peningkatan kualitas perencanaan, proses, dan hasil pendidikan dan atau pembelajaran pada RA, MI, MTs, MA, dan/atau MAK. Pada Bab VIPMA Nomor 2 Tahun 2012 tentang pengawas madrasah dan pengawas pendidikan agama Islam pada sekolah, pasal 9, ayat 2 huruf h menjelaskan bahwa salah satu kompetensi manajerial yang harus dikuasai oleh pengawas adalah memahami standar nasional pendidikan dan pemanfaatannyauntuk membantu kepala madrasah dalam mempersiapkan akreditasi. Keluarnya PMA ini tentu lebih mempertegas keteguhan niat dan usaha pemerintah dalam memfungsikan pengawas sebagai pengawal program-program pendidikan madrasah, khususnya yang terkait dengan peningkatan mutu.

Sebagai salah satu pilar penjamin mutu pendidikan, pengawas memiliki tugas dan wewenang untuk membina dan memantau penilaian dan pelaporan penerapan standar nasional pendidikan di madrasah. Sejauh ini belum diperoleh informasi spesifik tentang bagaimana pengawas Kota Serang melaksanakan tugas tersebut. Bagaimana desain perencanaan pembinaannya, seperti apa program pembinaan dan pemantauannya dilaksanakan, apa saja hasil yang telah diperoleh serta kendala-kendala apa saja yang ditemui dalam pelaksanaan tugas dan wewenang tersebut.

Dalam kaitan inilah studi tentang evaluasi pengawasan dalam pembinaan dan pemantauan pemenuhan standar nasional pendidikan di madrasah Kota Serang perlu dilakukan. Mengingat upaya pemenuhan SNP bukan hanya menjadi tanggungjawab kepala madrasah, tetapi juga tanggungjawab seluruh komponen yang terkait dengan penyelenggaraan pendidikan di madrasah. Dalam studi kali ini peran pengawas (baca: pengawas madrasah) menjadi fokus studi.

\section{Tujuan dan Kegunaan}

Penelitian ini bertujuan untuk mengetahui sejauhmana pembinaan dan pemantauan SNP telah dilaksanakan, serta mengungkap persoalan-persoalan yang dihadapi pengawas di lapangan. Hasil studi ini dapat dijadikan sebagai bahan pengayaan informasi dan bahan pertimbangan dalam pengambilan kebijakan peningkatan peran pengawas dalam membina dan memantau pemenuhan SNP di madrasah.

\section{Metodologi}

Studi dilakukan dengan Focus Group Discussion (FGD) atau sering disebut diskusi kelompok terarah yang dilakukan berulangulang sesuai tingkat kebutuhan data dan informasi. Posisi peneliti bertindak sebagai moderator pengendali materi. Sementara peserta secara selektif dari pihak Kasi Mapenda Kantor Kemenag, Kelompok Kerja Pengawas (Pokjawas), Kelompok Kerja Guru (KKG) dan Musyawarah Guru Mata Pelajaran (MGMP) sebagai nara sumber utama dan beberapa orang guru sebagai peserta. Materi FGD meliputi proses penyusunan rancangan program, pelaksanaan program, dan capaian program serta kendalakendala yang ditemui dalam pelaksanaannya. Kajian dokumentasi dilakukan untuk menelaah dan mengkaji dokumen kepengawasan, khususnya dokumen kepengawasan yang terkait dengan program dan target capaiannya dalam pemenuhan SNP di madrasah. Observasi lapangan dilakukan secara acak ke madrasah tertentu berdasarkan hasil pembinaan dan pemantauan pengawas untuk melihat secara fisik madrasah yang telah memenuhi dan belum memenuhi SNP.

Data yang diperoleh (melalui FGD, pengamatan, dokumentasi, catatan lapangan, dan dokumen lainnya) dipelajari dan ditelaah ${ }^{3}$. Kemudian dianalisis untuk menemukan makna setiap kata/informasi, hubungan antara satu informasi dengan informasi yang lain dan memberikan tafsiran yang dapat diterima akal sehat dalam konteks masalah kepengawasan secara keseluruhan. Untuk itu data dipilah-pilah dan kemudian dikelompokkan sesuai rincian masalah masing-masing. Data atau informasi tersebut dihubung-hubungkan dan dibanding-bandingkan satu dengan yang

3 Lexy J Moleong.1998. Metode Penelitian Kualitatif. Bandung.Remaja Rosdakarya.h.190 
lain dengan menggunakan proses berpikir rasional, analitik, sintetik, kritik dan logis dicari persamaan dan perbedaannya. Selanjutnya dideskripsikan dan diberi interpretasi dan penarikan kesimpulan. ${ }^{4}$ Studi ini adalah studi kasus dengan lokus kepengawasan madrasah Kota Serang, Banten.

\section{Studi Terkait}

Berdasarkan hasil penelitian Puslitbang Pendidikan Agama dan Keagamaan tahun 2007, kegiatan supervisi yang dilakukan oleh para pengawas pada umumnya lebih banyak pada supervisi yang bersifat administratif ${ }^{5}$ dan belum menyentuh pada substansi esensial pembinaan pemantauan yang terkait dengan aspek-aspek tertentu kekurangan madrasah dalam pemenuhan SNP.

Hasil penelitian Puslitbang Pendidikan Agama dan Keagamaan tahun $2008^{6}$ menunjukkan bahwa dilihat dari kompetensinya, kesiapan pendidik dan tenaga kependidikan (MI dan MTs) berada dalam kategori cukup siap atau telah memenuhi standar nasional pendidikan (SNP) dengan rerata skore mencapai 3.76. Sedangkan dilihat dari kualifikasinya, pemenuhan SNP untuk guru MI dan M.Ts baru terpenuhi SNP sebesar $72 \%$, sementara untuk kepala madrasah terpenuhi sebesar $74 \%$, dan terendah adalah pencapaian SNP pengawas yaitu terpenuhi sebesar 66\%. Penelitian tahun 2009 tentang "Kesiapan Madrasah dalam Pemenuhan SNP (Standar Pengelolaan Pendidikan, Standar Pendidik dan Tenaga Kependidikan, Standar Sarana Prasarana) di MTsN"', menunjukkan hal yang tidak jauh berbeda bahwa MTsN baru memenuhi 60\% SNP untuk Standar Pengelolaan, 61\% untuk Standar Pendidik dan

4 Hadari Nawawi.1996. Penelitian Terapan. Gadjah Mada University Press. Jakarta.h.190.

5 Puslitbang Pendidikan Agama dan Keagamaan.2010. Sinopsis Kajian Pendidikan Agama dan Keagamaan Tahun 2006-2009. Jakarta. h.175

6 Ibid. h.267

${ }^{7}$ Puslitbang Pendidikan Agama dan Keagamaan. 2010. Kesiapan Madrasah dalam Pemenuhan SNP (Standar Pengelolaan Pendidikan, Standar Pendidik dan Tenaga Kependidikan, Standar Sarana Prasarana)di MTsN.Jakarta.h.34
Tenaga Kependidikan dan 58\% untuk Standar Sarana Prasarana. Ini berarti bahwa madrasah pada umumnya belum memenuhi SNP pada tiga komponen tersebut.

Hasil penelitian tahun 2010 yang juga dilakukan oleh Puslitbang Pendidikan Agama dan Keagamaan terhadap empat komponen SNP (Standar Proses, Standar Isi, Standar Penilaian dan Standar Kompetensi Lulusan) menunjukkan bahwa: 1) Pemenuhan Standar Proses yang dilihat melalui empat indikator yaitu perencanaan proses pembelajaran, pelaksanaan proses pembelajaran, penilaian hasil pembelajaran dan pengawasan proses pembelajaran, hasilnya menunjukkan bahwa madrasah belum memenuhi SNP dan masuk kategori kurang dengan skor 2.8 atau 56\% memenuhi SNP. 2) Pemenuhan komponen Standar Isi yang dilihat melalui tiga indikator yaitu kerangka dasar dan struktur kurikulum, beban belajar dan kalender akademik, hasilnya menunjukkan bahwa madrasah telah memenuhi SNP dan masuk kategori cukup dengan skor 3.0 atau $60 \%$ memenuhi SNP. 3) Pemenuhan komponen Standar Penilaian yang dilihat melalui tiga indikator yaitu prinsip-prinsip penilaian, teknik dan instrumen penilaian serta mekanisme dan prosedur penilaian, hasilnya menunjukkan bahwa madrasah belum memenuhi SNP dan masuk kategori kurangdengan skor 2.7 atau 54\%memenuhi SNP. 4) Pemenuhan komponen Standar Kompetensi Lulusan (SKL) yang dilihat melalui dua indikator yaitu SKL minimal kelompok mata pelajaran dan SKL minimal mata pelajaran, hasilnya menunjukkan bahwa Standar kompetensi Lulusan di MTsN masuk kategori kurang dengan rerata skor 2.7 atau 54\%memenuhi SNP.

Berdasarkan uraian tersebut dapat disimpulkan bahwa, pemenuhan SNP di madrasah masih memerlukan perhatian. Pada umumnya madrasah yang telah dapat memenuhi 8 SNP adalah madrasah negeri yang dikelola pemerintah. Sementara madrasah swasta masih terkendala berbagai permasalahan-permasalahan umum yang dihadapi oleh lembaga pendidikan yang dikelola swasta. 


\section{KAJIAN LITERATUR}

Menurut Chelimsky ${ }^{8}$ (1989) evaluasi program merupakan penilaian terhadap efektivitas, implementasi, dan desain program. Sementara Brinkerhoff' et al (1990) menyebutkan diantara aspek atau dimensi evaluasi program meliputi hasil (impacts or outcomes), dan implementasi atau proses, serta tujuan dan rencana(goals and plans). Dengan demikian rencana program dan implementasi program merupakan dua aspek dari evaluasi program.

Evaluasi program bertujuan untuk melihat apakah program dirancang, dilaksanakan, dan bermanfaat bagi pihak-pihak yang terlibat dalam program. Pada pelaksanaannya evaluasi program bermaksud mencari informasi sebanyak mungkin untuk mendapatkan gambaran rancangan dan pelaksanaan program. Hasil Evaluasi tersebut akan digunakan bagi pihak yang berkepentingan untuk mengambil keputusan. Salah satu tujuan dari evaluasi program menurut Langbein dan Felbinger ${ }^{10}$ adalah evaluasi terhadap implementasi suatu program.

Stepphen Isaac 1986 (dalam Arikunto $^{11}$, 2004) membedakan adanya empat hal yang dipergunakan untuk membedakan ragam model evaluasi, yaitu:

a. berorientasi pada tujuan (goal oriented)

b. berorientasi pada keputusan (decision oriented)

c. berorientasi pada kegiatan dan orangorang yang menanganinya (transactional oriented) dan

d. berorientasi pada pengaruh dan dampak program (research oriented)

${ }^{8}$ Chelimsky, Eleaner.1989. Program Evaluation: Pattern and Direction. Scond Edition.Washington,DC. The American Society for Public Administration.

${ }^{9}$ Brinkenhoff, Robert O et. Al 1990. Program Evaluation, A Practitioner's Guide for Trainers and Education. Boston: Kluwer-Nijhoff Publishing.

${ }^{10}$ Longbein, Laura dan Claire L. Felbinger. 2006. Public Program Evaluation. New York: ME Sharpe.Inc.

${ }^{11}$ Suharsimi Arikunto dan Safrudin Cepi. 2004. Evaluasi Program Pendidikan; Pedoman Teoritis Praktis bagi Praktisi Pendidikan.Jakarta: Bumi Aksara.h. 37
Kaufman dan Thomas membedakan model evaluasi menjadi delapan, yaitu:

1) Goal oriented evaluation adalah model evaluasi yang dikembangkan oleh Tyler, dimana objek pengamatan model evaluasi ini adalah tujuan dari program. Evaluasi dilaksanakan secara terus menerus dan berkesinambungan untuk mengetahui ketercapaian pelaksanaan program.

2) Goal free evaluation model, adalah model evaluasi yang dikembangkan oleh Michael Scriven. Scriven menegaskan dalam melaksanakan evaluasi tidak memperhatikan tujuan khusus program, melainkan mengamati bagaimana terlaksananya program dan mencatat hal-hal yang sifatnya positif maupun negatif yang muncul dalam pelaksanaan program.

3) Formatif summatif evaluation model, dikembangkan oleh Michael Scriven. Pelaksanaan model evaluasi ini adalah ketika program sedang berjalan (evaluasi formatif) dan ketika program telah selesai dilaksanakan (evaluasi sumatif).

4) Countenance evaluation model, dikembangkan oleh Stake. Model ini sering disebut juga dengan model evaluasi pertimbangan. Maksudnya evaluator mempertimbangkan program dengan memperbandingkan kondisi hasil evaluasi program dengan yang terjadi diprogram lain, dengan objek sasaran yang sama dan membandingkan kondisi hasil pelaksanaan program dengan standar yang ditentukan oleh program tersebut.

5) Responsive evaluation model, dikembangkan oleh Stake.

6) CSE-UCLA evaluation model, dikembangkan oleh Alkin. Model ini meliputi empat tahap, yaitu need assessment, memusatkan pada penentuan masalah hal-hal yang perlu dipertimbangkan dalam program, kebutuhan uang dibutuhkan oleh program, dan tujuan yang akan dicapai;program planning, yaitu perencanaan program dievaluasi untuk mengetahui 
program disusun sesuai analisis kebutuhan atau tidak; formatif evaluation, yaitu evaluasi dilaksanakan pada saat program sedang berjalan; summative program, yaitu evaluasi dilakukan untuk mengetahui hasil dan dampak dari program serta untuk mengetahui ketercapaian program.

7) CIPP (context, input, process, product) evaluation model, dikembangkan oleh Stufflebeam. Evaluasi Konteks adalah evalusi terhadap kebutuhan, tujuan pemenuhan dan karakteristik individu yang menangani. Evaluasi Masukan mempertimbangkan kemampuan awal atau kondisi awal yang dimiliki oleh institusi untuk melaksanakan sebuah program. Evaluasi Proses yaitu evaluasi yang diarahkan pada sejauhmana program dilakukan dan sudah terlaksana sesuai dengan rencana. Evaluasi Hasil merupakan tahap akhir evaluasi dan akan diketahui ketercapaian tujuan, kesesuaian proses dengan pencapaian tujuan, dan ketepatan tindakan yang diberikan dan dampak dari program.

8) Discrepancy model dikembangkan oleh Provus. Model evaluasi ini lebih ditekankan untuk mengetahui kesenjangan yang terjadi pada setiap komponen progam. Evaluasi ini dimaksudkan untuk mengetahui tingkat kesesuaian antara standar yang sudah ditentukan dalam program dengan penampilan aktual dari program tersebut.

Berdasarkan uraian tersebut, model evaluasi yang dipilih dalam studi ini adalah model pendekatan goal free eavaluation model yaitu fokus pada bagaimana proses kerjanya program, dengan jalan mengidentifikasi penampilan-penampilan yang terjadi, baik hal-hal yang positif (yaitu hal-hal yang diharapkan) maupun hal-hal negatif (hal-hal yang tidak diharapkan).

Dengan demikian pelaksanaan evaluasi model goal free evaluation modeltidak spesifik memperhatikan tujuan khusus program, melainkan mencermati bagaimana terlaksananya program dan mencatat hal-hal yang positif (yang diharapkan) maupun hal-hal negatif (kelemahan-kelemahan) untuk merumuskan perbaikan lebih lanjut.

\section{HASIL DAN PEMBAHASAN}

\section{Deskripsi Lokus Penelitian}

Lokus penelitian adalah Kota Serang di propinsi Banten. Berdasarkan statistik 2011/2012 Kota Serang memiliki madrasah 121 unit, terdiri dari 17 Madrasah Aliyah (MA), 39 Madrasah Tsanawiyah (M.Ts), 15 Madrasah Ibtidaiyah (MI) dan 50 Raudlatul Athfal (RA).Adapun jumlah guru 1.006 orang guru, terdiri dari guru MA 202 orang guru, M.Ts 585 orang guru, MI 109 orang guru, dan 110 orang guru RA.

Tenaga fungsional pengawas 11 orang terdiri dari 2 orang pengawas wanita dan 9 orang pengawas laki-laki. Pendidikan S2,7 orang pengawas dan 4 orang pendidikan S1. Berdasarkan golongan kepegawaian 9 orang pengawas golongan IV/a, 1 orang golongan IV/b dan 1 orang golongan III/d. Dari segi usia 4 orang berusia antara 40-50 tahun dan 7 orang berusia 51 keatas. Dilihat dari sudut profil latar belakang pendidikan para pengawas sebagian besar S2, golongan kepegawaian III/d keatas, dan usia 40 keatas, hal ini telah mendekati pemenuhan persyaratan pengawas sesuai dengan permendiknas nomor 12 tahun 2007 tentang standar pengawas sekolah/madrasah lampiran A. 2.a pengawas SMP/M.Ts dan SMA/MA minimum S2 dengan basic S1 kependidikan. ${ }^{12}$

\section{Matrik program}

Matrik program pembinaan, pemantauan SNP yang dibuat dan disusun oleh para pengawas masih dalam bentuk yang cukup sederhana dan menyatu dengan program kepengawasan madrasah secara umum sebagai berikut:

${ }^{12}$ Permendiknas Nomor 12 Tahun 2007 tentang Standar Pengawas Sekolah/Madrasah. 
Tabel 1. Matrik Program Pemantauan Pelaksanaan 8 SNP ${ }^{13}$

\begin{tabular}{|c|c|c|c|c|}
\hline No. & $\begin{array}{l}\text { Pelaksanaan } \\
\text { SNP }\end{array}$ & Program/Kegiatan & $\begin{array}{l}\text { Target yang } \\
\text { diharapkan }\end{array}$ & $\begin{array}{l}\text { Hasil yang } \\
\text { dicapai }\end{array}$ \\
\hline 1 & 2 & 3 & 4 & 5 \\
\hline 1. & Standar Isi & $\begin{array}{l}\text { Dokumen KTSP belum } \\
\text { divalidasi } \\
\text { Silabus semua mata } \\
\text { pelajaran dikembangkan } \\
\text { KTSPnya }\end{array}$ & $\begin{array}{l}\text { Dokumen KTSP } \\
\text { sudah divalidasi } \\
\text { dan nilainya } 90 \% \\
\text { keatas }\end{array}$ & $\begin{array}{l}\text { Madrasah } 50 \% \\
\text { KTSP yang sdh } \\
\text { divalidasi } \\
80 \% \text { madrasah } \\
\text { telah mengem- } \\
\text { bangkan } 13 \text { mata } \\
\text { pelajaran }\end{array}$ \\
\hline 2. & Standar Proses & $\begin{array}{l}\text { Perangkat pembelajaran } \\
\text { guru } \\
\text { Pembelajaran di kelas } \\
\text { Peraturan Menteri } \\
\text { Guru dapat mengelabo- } \\
\text { rasi dan mengeksplorasi } \\
\text { kemampuan siswa }\end{array}$ & \begin{tabular}{|l|}
$100 \%$ guru \\
memiliki perangkat \\
pembelajaran \\
Guru dapat \\
menyampaikan \\
materi sesuai \\
dengan standar \\
kompetensinya \\
$90 \%$ guru dapat \\
mengelaborasi dan \\
mengeksplorasi \\
kemampuan siswa
\end{tabular} & $\begin{array}{l}80 \% \text { guru me- } \\
\text { miliki perangkat } \\
\text { pembelajaran } \\
90 \% \text { guru dapat } \\
\text { menyampaikan } \\
\text { materi } \\
75 \% \text { guru dapat } \\
\text { mengelaborasi } \\
\text { dan mengeksplo- } \\
\text { rasi kemampuan } \\
\text { siswa }\end{array}$ \\
\hline 3. & $\begin{array}{l}\text { Standar Kompe- } \\
\text { tensi Lulusan }\end{array}$ & $\begin{array}{l}\text { Seluruh siswa } \\
\text { dapat mengikuti standar } \\
\text { kompetensi lulusan }\end{array}$ & $\begin{array}{l}90 \% \text { siswa } \\
\text { mengikuti standar } \\
\text { kompetensi } \\
\text { lulusan }\end{array}$ & $\begin{array}{l}90 \% \text { siswa } \\
\text { mengikuti } \\
\text { standar kompe- } \\
\text { tensi lulusan }\end{array}$ \\
\hline 4. & $\begin{array}{l}\text { Standar Pendi- } \\
\text { dik dan Tenaga } \\
\text { Kependidikan }\end{array}$ & $\begin{array}{l}\text { Seluruh pendidik dan } \\
\text { tenaga kependidikan } \\
\text { memenuhi kulaifikasinya } \\
\text { Seluruh tenaga pendidik } \\
\text { terserttifikasi memenuhi } \\
\text { kualifikasinya }\end{array}$ & $\begin{array}{l}\text { 90\% pendidik dan } \\
\text { tenaga kependi- } \\
\text { dikan memenuhi } \\
\text { kualifikasi } 1 \\
\text { Seluruh tenaga } \\
\text { pendidik terser- } \\
\text { tifikasi }\end{array}$ & $\begin{array}{l}90 \% \text { pendidik } \\
\text { dan tenaga } \\
\text { kependidikan } \\
\text { memenuhi } \\
\text { kualifikasi } \$ 1 \\
50 \% \text { tenaga } \\
\text { pendidik terser- } \\
\text { tifikasi }\end{array}$ \\
\hline 5. & Standar Sarana & $\begin{array}{l}\text { Sarana prasarana } \\
\text { terpenuhi sesuai dengan } \\
\text { standar akreditasi } \\
\text { nasional }\end{array}$ & $\begin{array}{l}80 \% \text { masing-ma- } \\
\text { sing madrasah } \\
\text { harus sesuai } \\
\text { dengan standar } \\
\text { sarana prasarana } \\
\text { akreditasi }\end{array}$ & $\begin{array}{l}60 \% \text { masing-ma- } \\
\text { sing madrasah } \\
\text { sesuai dengan } \\
\text { standar sarana } \\
\text { prasarana } \\
\text { akreditasi }\end{array}$ \\
\hline 6. & $\begin{array}{l}\text { Standar Penge- } \\
\text { lolaan }\end{array}$ & $\begin{array}{l}\text { Pengelolaan keuangan } \\
\text { BOS harus dipertang- } \\
\text { gungjawabkan sesuai } \\
\text { aturan. }\end{array}$ & $\begin{array}{l}100 \% \text { madrasah } \\
\text { penerima BOS } \\
\text { dapat melaksa- } \\
\text { nakan pelaporan } \\
\text { keuangan secara } \\
\text { akuntabel }\end{array}$ & $\begin{array}{l}50 \% \text { madrasah } \\
\text { penerima BOS } \\
\text { dapat melaksa- } \\
\text { nakan pelporan } \\
\text { keuangan secara } \\
\text { akuntabel }\end{array}$ \\
\hline 7. & $\begin{array}{l}\text { Standar } \\
\text { Pembiayaan }\end{array}$ & $\begin{array}{l}\text { Pembiayaan invesatasi } \\
\text { bagi siswa baru semini- } \\
\text { mal mungkin }\end{array}$ & $\begin{array}{l}100 \% \text { madrasah } \\
\text { memiliki RKA/ } \\
\text { RKAKL secara } \\
\text { jelas }\end{array}$ & $\begin{array}{l}80 \% \text { madrasah } \\
\text { memiliki RKA } \\
\text { RKAKL secara } \\
\text { jelas }\end{array}$ \\
\hline 8. & $\begin{array}{l}\text { Standar } \\
\text { Penilaian }\end{array}$ & $\begin{array}{l}\text { Program LHBS dapat } \\
\text { dipertanggungjawabkan } \\
\text { kepada stakeholders } \\
\text { Siswa dapat menye- } \\
\text { lesaikan evaluasi } \\
\text { pembelajarannya }\end{array}$ & $\begin{array}{l}100 \% \text { guru } \\
\text { memiliki sistem } \\
\text { penilaian dan } \\
\text { buku nilainya } \\
100 \% \text { siswa dapat } \\
\text { menyelesaikan } \\
\text { evaluasi pembela- } \\
\text { jarannya }\end{array}$ & $\begin{array}{l}90 \% \text { guru } \\
\text { memiliki sistem } \\
\text { penilaian dan } \\
\text { buku nilainya } \\
90 \% \text { siswa dapat } \\
\text { menyelesaikan } \\
\text { evaluasi pembe- } \\
\text { lajrannya }\end{array}$ \\
\hline
\end{tabular}

\section{Analisis Rancangan Program}

Dalam perancangan program pembinaan dan pemantauan pelaksanaan standar nasional pendidikan, para pengawas mendasarkan pada hasil identifikasi masalah yang ditemui pada program tahun-tahun sebelumnya. Temuan

${ }^{13}$ Kemenag Kota Serang.2012/2013. Program Kepengawasan Pokjawas. Serang.h.8 tersebut antara lain masalah kinerja guru dan kepala madrasah yang belum optimal; masih rendahnya kemampuan profesional guru; belum terpenuhinya standar tenaga pendidik dan kependidikan; sarana prasarana yang belum mencukupi; pemenuhan akreditasi; kesejahteraan guru dan kepala madrasah; citra madrasah dan sebagainya.

Hasil identifikasi masalah tersebut kemudian dituangkan dalam program tahunan, target yang diharapkan dan hasil yang telah dicapai (Tabel 1). Pada aspek target yang diharapkan menggunakan pendekatan target-target persentase seperti sekian persen madrasah memiliki dokumen KTSP dan sekian persen belum memiliki dan seterusnya. Demikian juga halnya standar ukuran yang digunakan dalam melihat capaian program memiliki konsep yang yang sama yaitu persentase capaian. Berikut hasil analisis dan pembahasan masingmasing standar sebagai berikut:

\section{Standar Isi}

Dalam kaitan program pembinaan, pemantauan pemenuhan SNP yang terkait dengan standar isi misalnya program pembinaan dan pemantauan pemenuhan standar isi buatan pengawas hanya terdiri dari dua program yaitu program yang menyangkut validasi KTSP dan pengembangan silabusnya. Target yang diharapkan dari program ini adalah $90 \%$ dokumen KTSP telah divalidasi dan seluruh mata pelajaran telah dikembangkan KTSPnya. Sementara hasil capaiannya adalah 50\% KTSP telah divalidasi dan $80 \%$ madrasah telah mengembangkan KTSP-nya.

Idealnya program tersebut menggunakan indikator pemenuhan SNP yang lebih terukur untuk dapat memberikan bantuan pembinaan. Indikator tersebut misalnya adalah sebagai berikut, yaitu madrasah telah melaksanakan KTSP untuk semua mata pelajaran, telah melaksanakan kegiatan pengembangan KTSP sesuai ketentuan, ada dokumen kurikulum yang berupa dokumen I (buku KTSP) dan silabus semua mata pelajaran, ada dokumen 
kegiatan remedial dan pengayaan oleh guru, ada kegiatan BK dan ekstra kurikuler, terdapat Standar Kompetensi (SK) untuk semua mata pelajaran dan menghitung hari-hari efektif, minggu dan hari libur dalam dokumen kalender akademik.

\section{Standar Proses}

Program yang terkait dengan Standar Proses buatan pengawas memiliki tiga program yaitu pemenuhan perangkat pembelajaran guru, pembelajaran di kelas berlangsung sesuai peraturan menteri serta guru dapat mengelaborasi dan mengeksplorasi kemampuan siswa. Target yang ingin diraih melalui program ini adalah $100 \%$ guru memiliki perangkat pembelajaran, guru dapat menyampaikan materi sesuai dengan standar kompetensinya dan $90 \%$ guru dapat mengelaborasi dan mengeksplorasi kemampuan siswa. Target capaian yang diperoleh adalah hanya $80 \%$ guru yang memiliki perangkat pembelajaran, $90 \%$ guru dapat menyempaikan materi dan $75 \%$ guru dapat mengelaborasi dan mengeksplorasi kemampuan siswa.

Sementara Indikator pemenuhan Standar Proses untuk lebih memfokuskan pembinaan seyogianya dapat dibuat lebih rinci misalnya; guru-guru mengembangkan silabus secara mendiri, guru-guru menyusun RPP sebelum mengajar, guru-guru melaksanakan proses pembelajaran sesuai KTSP, Kepala Sekolah melaksanakan Supervisi Pembelajaran (perencanaan, pelaksanaan, dan penilaian), dan Kepala Sekolah menindak lanjuti hasil pengawasan.

\section{Standar Kompetensi Lulusan}

Program buatan pengawas yang terkait dengan SKL adalah seluruh siswa dapat mengikuti standar kompetensi lulusan. Target yang ingin dicapai 90\% siswa dapat mengikuti standar kompetensi lulusan dan capaiannya adalah 90\% siswa mengikuti standar kompetensi lulusannya.
Indikator Standar Kompetensi Lulusan versi Kemdikbud adalah adanya dokumen Kriteria Ketuntasan Minimal (KKM) untuk kelompok Iptek, IPS dan Seni Budaya, guru mengajar dengan mengutamakan keterlibatan siswa secara aktif dalam proses belajar mengajar, guru melaksanakan proses pembelajaran CTL, menggunakan media pembelajaran lingkungan, melatih siswa berfikir kritis, kreatif dan inovatif, terdapat proses pembelajaran pembiasan. Siswa memperoleh pengalaman di bidang seni dan budaya, siswa dilatih memperoleh pengalaman berjiwa/sikap sportif, dan siswa diberi pengalaman dalam kehidupan sosial bermasyarakat dan bernegara.

\section{Standar Pendidik dan Tenaga Kependidikan}

Ada dua program pengawas yang terkait dengan standar PTK ini yaitu seluruh pendidik dan tenaga kependidikan memenuhi kualifikasi sesuai perundang-undangan dan seluruh tenaga pendidik tersertifikasi sesuai dengan kualifikasinya. Targetnya adalah $90 \%$ pendidik dan tenaga kependidikan memenuhi kulaifikasi S1 dan seluruh tenaga pendidik tersertifikasi. Capaiannya adalah $90 \%$ pendidik telah memenuhi kulaifikasi dan 50\% telah tersertifikasi.

Sementara indikator yang terkait dengan standar pendidik dan tenaga kependidikan seyogianya adalah meliputi; $75 \%$ kualifikasi guru S.1 / D.IV; 75 \% guru mengajar sesuai latar belakang ijazah; Kepala Sekolah, Wakasek dan Kepala Tata Usaha pendd. S.1; Punya Tata Usaha memadai; Ada tenaga laboran, pustakawan dan penjaga sekolah yang cukup; Tenaga Laboran, Pustakawan dan Tenaga Administrasi $75 \%$ sesuai keahlian pendidikan; Pendidik dan Tendik $90 \%$ berperilaku baik; kepala Sekolah memiliki pengalaman sebagai pendidik; Memiliki guru BK yang cukup memadai; Kepala Sekolah cukup melaksanakan supervisi.

\section{Standar Sarana Prasarana}

Berdasarkan indikator pemenuhan SNP mengenai sarana prasarana yaitu, memiliki 
luas lahan sesuai ketentuan; memiliki gedung sekolah sendiri; memiliki ruang Kepala Sekolah dengan ruang TU; sarana/ prasarana belajar yang cukup; ada ruang laboratorium (IPA Biologi, IPA Fisika, Ruang Perpustakaan dan Ruang Keterampilan; ada ruang Bimbingan Konseling, Organisasi Siswa Intra Sekolah, Palang Merah Remaja / Usaha Kesehatan Madrasah; ada ruang guru; ada tempat ibadah; ada fasilitas olah raga (alat dan lapangan); dan terdapat terdapat gudang dan aula. Kenyataannya program pengawas yang terkait sarana prasarana hanya memiliki satu item program yang menyangkut standar saranaprasarana yaitu program pemenuhan sarana prasarana sesuai standar akreditasi nasional. Targetnya $80 \%$ madrasah harus memiliki sarana sesuai dengan standar sarana dan parasarana akreditasi. Tetapi capaian programnya baru $60 \%$ madrasah yang telah memenuhi standar sarana prasana sesuai akreditasi. Artinya terdapat 40\% madrasah di Kota Serang yang standar sarana prasarananya berada dibawah standar akreditasi.

\section{Standar Pengelolaan}

Standar pengelolaan yang diprogramkan hanya menyangkut pengelolaan keuangan BOS yaitu program BOS harus dipertanggungjawabkan sesuai aturan. Targetnya $80 \%$ madrasah penerima BOS dapat melaksanakan pelaporan keuangan secara akuntabel. Capaian programnya hanya 50\% madrasah penerima BOS yang dapat mempertanggungjawabkan laporan keuangan secara akuntabel. Sementara 50\% lainnya tidak dapat mempertanggungjawabkan dana BOS tersebut sesuai ketentuan yang berlaku.

Jika program, target dan capaiannya tersebut dikaitkan dengan 10 indikator pemenuhan standar pengelolaan, yaitu terdapat rumusan visi-misi sekolah; memiliki program kerja menengah (4 tahun) dan program kerja tahunan; memiliki dokumen pengelolaan 8 Standar Nasional Pendidikan; memiliki struktur organisasi sekolah; ada program pemberdayaan pendidik dan tenaga kepandidikan; terdapat dokumen pengelolaan pembiayaan; ada dokumen pembinaan kesiswaan; ada dokumen pengelolaan sarana dan prasarana; terdapat aturan untuk menciptakan tata tertib dan keamanan sekolah; ada dokumen pengelolaan pembelajaran; ada dokumen supervisi guru; dan ada dokumen pengelolaan pegawai, nampak bahwa program yang dicanangkan pengawas tersebut bukan dalam kaitan pengelolaan saja, tetapi bercampur dengan standar pembiayaan.

\section{Standar Pembiayaaan}

Program pengawas terkait standar pembiayaan hanya satu yaitu pembiayaan investasi bagi siswa baru seminimal mungkin. Targetnya 100\% sekolah memiliki RKA/KL secara jelas. Capaiannya $80 \%$ madrasah memiliki RKA/KL secara jelas. Antara program yang dicanangkan dengan target yang akan dicapai tidak sinkron, antara biaya investasi dengan kepemilikan RKA/KL. Seharusnya target capaiannya adalah $100 \%$ biaya investasi siswa baru seminimal mungkin.

Sementara tuntutan yang terkait dengan standar pembiayaan meliputi berbagai aspek yaitu; kepemilikan dokumen nilai aset; terdapat Rencana Kerja Anggaran Sekolah (RKAS); memiliki modal kerja/anggaran untuk pembiayaan sekolah; memiliki data pembayaran gaji/ upah; memiliki anggaran pembiayaan sarana dan prasarana; memiliki anggaran pembiayaan ujian semester, ujian sekolah dan UN; memiliki data sumber dana yang jelas dan teratur; dan terdapat laporan pertanggung jawaban keuangan tahunan.

\section{Standar Penilaian}

Dalam kaitan dengan standar penilaian terdapat 10 indikator yang harus dipenuhi sesuai pedoman pemenuhan SNP, yaitu: setiap guru merancang kriteria penilaian yang di muat dalam silabus; setiap silabus mata pelajaran dilengkapi dengan indikator pencapaian Kompetensi Dasar (KD); guru memiliki dan me- 
ngembangkan berbagai instrumen penilaian; setiap mata pelajaran dilengkapi dengan pedoman penilaian sesuai bentuk dan tekniknya; guru memiliki dokumen hasil penilaian; guru menganalisis hasil penilaian untuk kegiatan perbaikan; setiap mata pelajaran di tetapkan KKM nya; madrasah memiliki program evaluasi semester dan ujian akhir; marasah memiliki dokumen hasil ujian 2 tahun terakhir; dan madrasah memiliki dokumen penerbitan raport, SKHUN dan Ijazah 2 tahun terakhir.

Dari 10 indikator diatas, pengawas madrasah baru memiliki dua program yang dirancang mengenai standar penilaian yaitu laporan hasil belajar siswa dapat dipertanggungjawabkan kepada stakeholder dan seluruh siswa dapat menyelesaiakan evaluasi belajarnya. Dengan dua program tersebut, pelacakan kelemahan maupun kekurangan dalam pemenuhan standar penilaian yang dituntut oleh perundangundangan akan semakin sulit dipenuhi karena sifat program yang global.

Berdasarkan uraian masing-masing standar diatas dapat disimpulkan bahwa perencanaan program yang disusun oleh para pengawas, khususnya yang terkait dengan perencanaan pembinaan dan pemanatauan 8 SNP di madrasah, masih dalam batas-batas minimal dan global. Inti permasalahannya antara lain terletak pada belum adanya pembekalan khusus yang diberikan kepada pengawas terkait dengan program pembinaan, pemantauan pemenuhan SNP. Misalnya, materi perencanaan pembinaan pemantauan pemenuhan SNP, strategi pembinaannya dan alternatif-alternatif pemenuhannya. Konsenterasi kepengawasan yang berjalan selama ini masih terfokus pada hal-hal yang sifatnya konvensional yaitu pembinaan yang sifatnya administratif pembelajaran belum fokus pada aspek-aspek kekurangan madrasah dalam pemenuhan 8 SNP. ${ }^{14}$

\section{Analisis Program Pembinaan}

Berdasarkan analisis terhadap format program kepengawasan pembinaan dan pe-

${ }^{14} \mathrm{FGD} 30$ Oktober 2012. mantauan SNP yang digunakan pengawas (tabel 2) terdiri dari 6 kolom dengan kolom 1 nomor urut, kolom 2 pelaksanaan SNP, kolom 3 program kegiatan, kolom 4 target yang diharapakan, kolom 5 hasil yang dicapai dan kolom 6 keterangan, nampak tidak/belum sinkron dengan tabel langkah pemenuhan SNP pada berbagai tingkat satuan pendidikan (tabel 3).

Tabel 2. Matrik Pembinaan Pemantauan Pemenuhan SNP

\begin{tabular}{|c|c|l|l|l|}
\hline No. & $\begin{array}{c}\text { Pelak- } \\
\text { sanaan } \\
\text { SNP }\end{array}$ & $\begin{array}{c}\text { Program/ } \\
\text { Kegiatan } \\
\mathbf{2 0 1 1 / 2 0 1 2}\end{array}$ & $\begin{array}{l}\text { Target yang } \\
\text { diharapkan } \\
\mathbf{2 0 1 2 / 2 0 1 3}\end{array}$ & $\begin{array}{c}\text { Hasil yang } \\
\text { dicapai }\end{array}$ \\
\hline 1 & 2 & 3 & 4 & 5 \\
\hline 1. & $\begin{array}{l}\text { Stan- } \\
\text { dar Isi }\end{array}$ & $\begin{array}{l}\text { Dokumen } \\
\text { KTSP belum } \\
\text { divalidasi } \\
\text { Silabus } \\
\text { semua mata } \\
\text { pelajaran di- } \\
\text { kembangkan } \\
\text { KTSPnya }\end{array}$ & $\begin{array}{l}\text { Dokumen } \\
\text { KTSP sudah } \\
\text { divalidasi dan } \\
\text { nilainya 90\% } \\
\text { keatas }\end{array}$ & $\begin{array}{l}\text { Madrasah } \\
50 \% \text { KTSP } \\
\text { yang sdh } \\
\text { divalidasi } \\
80 \% \text { madra- } \\
\text { sah telah } \\
\text { mengembang- } \\
\text { kan 13 mata } \\
\text { pelajaran }\end{array}$ \\
\hline
\end{tabular}

(Dikutip sesuai dokumen asli pokjawas)

Dalam pedoman pemenuhan SNP Kemdikbud (tabel 3) lebih ditegaskan pada problem dan upaya pemenuhannya yaitu kolom 1indikator pemenuhan SNP, kolom 2 alasan pemilihan indikator, kolom 3 langkah pemenuhan, kolom 4 personil, kolom 5 waktu/durasi pemenuhan dan kolom 6 hasil. Kita ambil contoh kolom 1: Kepala sekolah memiliki kualifikasi pendidikan minimal. Kolom 2, merupakan syarat formal yang harus dipenuhi dari Permendiknas No. 13 tahun 2007 tentang standar kepala Kepala sekolah; kolom 3 melanjutkan studi S1/D4 dan Mengajukan beasiswa S1/D4 ke Pemerintahan kab./kota atau ke Pusat atau perusahaan sekitar madrasah; kolom 4 Kepala sekolah; kolom 5 sepanjang tahun ajaran; kolom 6 Kepala sekolah dapat menyelesaikan studi minimal S1/D4. 
Tabel 3. Program Pemenuhan SNP ${ }^{15}$

\begin{tabular}{|c|c|c|c|c|c|}
\hline $\begin{array}{c}\text { Peme- } \\
\text { nuhan } \\
\text { SNP }\end{array}$ & $\begin{array}{c}\text { Alasan } \\
\text { Pemilihan } \\
\text { Indikator }\end{array}$ & $\begin{array}{c}\text { Lang- } \\
\text { kah } \\
\text { Peme- } \\
\text { nuhan }\end{array}$ & $\begin{array}{c}\text { Per- } \\
\text { sonil }\end{array}$ & $\begin{array}{l}\text { Waktul } \\
\text { Durasi }\end{array}$ & Hasil \\
\hline 1 & 2 & 3 & 4 & 5 & 6 \\
\hline $\begin{array}{l}\text { Kamad } \\
\text { memiliki } \\
\text { kualifika- } \\
\text { si pen- } \\
\text { didikan } \\
\text { minimal }\end{array}$ & $\begin{array}{l}\text { Syarat } \\
\text { formal } \\
\text { yang harus } \\
\text { dipenuhi } \\
\text { sesuai } \\
\text { Permen- } \\
\text { diknas No: } \\
\text { 13/2007 }\end{array}$ & $\begin{array}{l}\text { Melan- } \\
\text { jutkan } \\
\text { studi } \\
\text { S1/D4 }\end{array}$ & $\begin{array}{l}\text { Ka- } \\
\text { mad }\end{array}$ & $\begin{array}{l}\text { Sepan- } \\
\text { jang } \\
\text { tahun } \\
\text { ajaran }\end{array}$ & $\begin{array}{l}\text { Kamad } \\
\text { dapat } \\
\text { menye- } \\
\text { lesaikan } \\
\text { studi S1/ } \\
\text { D4 }\end{array}$ \\
\hline
\end{tabular}

(Dikutip sesuai dokumen Depdikbud)

Berdasarkan materi masing-masing kolom dalam format kepengawasan buatan pengawas secara jelas dapat dikatakan bahwa penyusunan format program pembinaan tersebut belum sepenuhnya mengacu pada program pemenuhan standar nasional pendidikan. Materi-materi kolom tersebut sifatnya masih sangat global, sehingga sulit diukur untuk dijadikan bahan pembinaan bagi kepala madrasah. Bahkan untuk melacak madrasah mana saja yang memerlukan pembinaan dan pemenuhan serta pada aspek standar apa saja kelemahannya tidak dapat diketahui melalui isian format buatan pengawas tersebut. Sebaliknya, pada program pemantauan pemenuhan standar nasional pendidikan buatan Kemdikbud cukup terukur dan mudah memantau perkembangannya.

Secara umum para pengawas menegaskan bahwa mereka menghadapi berbagai kendala dalam melaksanakan tugas-tugas tersebut, khususnya tugas pembinaan dan pemantauan pemenuhan standar nasional pendidikan. Diantara kendala tersebut antara lain belum maksimalnya sosialisasi SNP dalam perspektif tugastugas kepengawasan (pengawas secara jujur mengatakan bahwa mereka belum memahami SNP dengan baik khususnya yang menyangkut bagaimana merancang program pemenuhannya), pengawas lebih berkonsenterasi pada tugas-tugas kepengawasan bidang akademik (sesuai dengan latar belakang pendidikan dan

${ }^{15}$ Kemdikbud.2012. Pedoman Pemenuhan SNP Sekolah/Madrasah (Pusat Penjaminan Mutu Pendidikan). Jakarta.h.33 profesi awal mereka), pengawas menyadari masih sangat memerlukan pendalaman terkait SNP dan strategi pemenuhannya di madrasah. Itulah antara lain sebabnya, mengapa pembinaan dan pemantauan pemenuhan SNP di madrasah belum berjalan maksimal sesuai dengan yang diharapkan.

\section{Analisis Hasil Pembinaan}

Berdasarkan rancangan dan matrik program yang telah disusun oleh pengawas menunjukkan bahwa capaian program yang di peroleh adalah capaian hasil yang belumfokus pada upaya merumuskan langkah-langkah pemenuhan kekurangan-kekurangan standar nasional pendidikan di madrasah. Sekaligus, hasil tersebut belum menunjukkan pada aspek standar mana yang memerlukan upaya pembinaan oleh pengawas dan strategi pemenuhan apa yang dapat ditawarkan sebagai alternatif pemecahannya.

Seyogianya pihak pengelola madrasah, khususnya kepala madrasah, merasakan adanya perubahan yang terkait dengan berbagai upaya yang diprogramkan oleh pengawas. Namun, berdasarkan hasil FGD menunjukkan bahwa pada umumnya pengawas belum secara terencana memaksimalkan fungsinya dalam pemantauan pemenuhan SNP. Dari enam fungsi pengawas yaitu a). penyusunan program pengawasan di bidang akademik dan manajerial;b). pembinaan dan pengembangan madrasah;c). pembinaan, pembimbingan, dan pengembangan profesi guru madrasah;d). pemantauan penerapan standar nasional pendidikan;e). penilaian hasil pelaksanaan program pengawasan; danf). pelaporan pelaksanaan tugas kepengawasan,fungsi nomor empat tentang pemantauan penerapan standar nasional pendidikan menjadi fungsi yang belum mendapat perhatian maksimal bahkan cenderung terabaikan oleh para pengambil kebijakan. Fungsi yang bersifat administratif pembelajaran menjadi fungsi yang paling menonjol dilakukan oleh para pengawas.

Pada sisi lain, berbagai dokumen yang diadakan dan dibuat oleh para pengawasju- 
ga masih sebatas pemenuhan syarat formal administratif belum menjadi pedoman kerja yang formal dalam pelaksanaan tugas yang terkait dengan SNP. Oleh karena itu sebagian besar madrasahbelum sepenuhnya merasakan mendapatkan pembinaan, pemantauan pemenuhan standar nasional pendidikan dengan dasar dan implementasi perkembangan pemenuhan SNP yang terukur. Kehadiran PMA Nomor 12 tahun 2012 tentang pengawas madrasah dan pengawas pendidikan agama Islam pada sekolah mengukuhkan semangat akan pentingnya penguatan fungsi pengawas dalam penjaminan mutu pendidikan dan secara khusus dalam mengawal pembinaan, pemantauan pemenuhan standar nasional pendidikan di madrasah.

\section{PENUTUP}

\section{Kesimpulan}

Pada umumnya pengawas lebih dominan melakukan pembinaan pada aspek administratif pembelajaran, belum masuk secara spesifik pada sapek-aspek tertentu kelemahan madrasah dalam pemenuhan SNP. Meskipun demikian, dalam batas-batas tertentu perencanaan program yang terkait pembinaan, pemantauan dan pemenuhan SNP di madrasah telah disusun dan dimiliki oleh para pengawas.

Program pembinaan dan pemantauan SNP yang disusun oleh pengawas dikesankan sebagai dokumen pemenuhan administratif laporan. Perencanaan program tersebut masih memerlukan penyempurnaan secara terus menerus, terutama pada poin-poin kelemahan madrasah dalam pemenuhan SNP.

Peran pengawas yang terkait dengan pemantauan, pembinaan pemenuhan SNP di madrasah dihadapkan pada berbagai kendala. Antara lain,persepsi pihak madrasah terhadap pengawas belum banyak berubah, pengawas belum diposisikansebagai mitra kerja madrasah. Pada sisi lain terbatasnya kewenangan yang diberikan kepada para pengawas madrasah masih dirasakan dalam pelaksanaan tugas sehari-hari.

\section{Saran}

Peran pengawas sebagai fasilitator dan mitra kerja madrasah dalam menyusun perencanaan program pemenuhan SNP perlu ditingkatkan melalui pemberdayaan pengawas sebagai penjamin mutu pendidikan. Oleh karena itu diperlukan diklat pengayaan dan penguatan fungsi pengawas dalam pemenuhan SNP di madrasah.

\section{SUMBER BACAAN}

Arikunto, Suharsimi. 1988. Penilaian Program Pendidikan. Jakarta: Ditjen Dikti Proyek Pengembangan Lembaga Pendidikan Tenaga Kependidikan.

-dan Safrudin Cepi. 2004. Evalusi Program Pendidikan; Pedoman Teoritis Praktis bagi Praktisi Pendidikan. Jakarta: Bumi Aksara

2005. Dasar-Dasar Evaluasi Pendidikan (edisi revisi). Jakarta: Bumi Aksara.

Brinkenhoff, Robert $O$ et. Al 1990. Program Evaluation, A Practitioner's Guide for Trainersand Education. Boston: Kluwer-Nijhoff Publishing.

Chelimsky, Eleaner. 1989. Program Evaluation: Pattern and Direction. Scond Edition.Washington DC. The American Society for Public Administration.

Departemen Pendidikan Nasional RI. 2005.Peraturan Pemerintah Republik Indonesia No. 19 tahun 2005 tentang Standar Nasional Pendidikan, Jakarta.

Ditjen Menajemen Dikdas dan Menengah, Depdiknas. 2008. Instrumen Kinerja

Sekolah Minitoring dan Evaluasi SSN. WWW.Google.Com.

Farida Yusuf, Tayibnafis, 2000. Evaluasi Program. Jakarta:Rieneka Cipta.

Kemenag Kota Serang.2012.Program Pengawasan POKJAWAS Kota Serang, TA 2012/2013. 
Kemdikbud. 2012. Pedoman Pemenuhan SNP Sekolah/Madrasah (Pusat Penjaminan Mutu Pendidikan). Jakarta.

Longbein, Laura dan Claire L. Felbinger. 2006. Public Program Evaluation. New York: ME Sharpe.Inc.

Moleong, Lexy J. 1998. Metode Penelitian Kualitatif. Bandung:Rosdakarya.

Nawawi, Hadari. 1996. Penelitian Terapan. Yogyakarta: Gadjah Mada University Press.

Permendiknas Nomor 12 Tahun 2007 tentang Standar Pengawas Sekolah/Madrasah.

Puslitbang Pendidikan Agama dan Keagamaan. 2010. Sinopsis Kajian Pendidikan Agama dan Keagamaan Tahun 2006-2009. Jakarta.
Puslitbang Pendidikan Agama dan Keagamaan. 2010. Kesiapan Madrasah dalam Pemenuhan SNP(Standar Pengelolaan Pendidikan, Standar Pendidik dan Tenaga Kependidikan, Standar Sarana Prasarana) di MTsN.Jakarta.

Sugiyono. 2009. Metode Penelitian Kuantitatif Kualitatif dan R \& D. Bandung: Alfabeta.

Tuijnman, C, Albert \& Postlethwaite, Neville, T. (ed) .1994. Monitoring The

Standards Of Education. Great Britain: Redwood Books Pergamon

Undang-Undang Nomor 20 Tahun 2003 tentang Sistem Pendidikan Nasional (2003). Jakarta: Lembaran Negara. 